Original Research

\title{
Hubungan Pemilihan Teknologi dan Pencapian Kompetensi dalam Metode Pembelajaran Daring
}

\author{
Ng Melissa Angga ${ }^{1 *}$ \\ ${ }^{1}$ Fakultas Teknik Universitas Surabaya, Raya Kalirungkut Surabaya-Indonesia 60293 \\ *corresponding author: melissa@staff.ubaya.ac.id
}

\begin{abstract}
Online learning has been adapted throughout educational institution recently whereas adoption become inevitably especially during pandemic. Various methods have been adopted by educators with less experience in conducting online learning, thus it is unsurprising that its implementation seems to be a trial and error and has been criticized by various parties. In addition, educators are actually still unfamiliar with various technologies that are widely used in various learning methods. This situation become an obstacle in the application of learning methods since there are too many learning burdens that must be overcome by educators, namely mastery of a variety of methods. and various technological variations without the support of data about the most optimal methods and technologies to use. This study aims to provide an overview of the measurement of the effective usage of technology in various online learning methods associated with the ultimate goal of learning as an important insight for teaching staff in selecting technology and method to be mastered.
\end{abstract}

Keywords: online, learning, technologies, effective

\begin{abstract}
Abstrak- Pembelajaran daring adalah wacana yang semakin kencang digaungkan, dan menjadi tidak terhindarkan khususnya pada saat pandemi. Berbagai metode diadopsi oleh pengajar yang mayoritas belum berpengalaman menyelenggarakan pembelajaran daring, karena itu tidak heran sistem pelaksanaannya terkesan trial and error dan banyak dikritisi oleh berbagai pihak. Selain itu, guru dan tenaga pengajar sebenarnya masih asing terhadap berbagai teknologi yang banyak dimanfaatkan dalam penerapan berbagai metode pembelajaran tersebut $\mathrm{Hal}$ ini menambahkan hambatan dalam penerapan metode pembelajaran karena dalam satu kesempatan ada terlalu banyak beban belajar yang harus diatasi oleh tenaga pengajar yaitu penguasaan berbagai variasi metode dan berbagai variasi teknologi tanpa didukung data mengenai metode dan teknologi yang paling optimal untuk dipergunakan. Penelitian ini bertujuan untuk memberikan gambaran pengukuran efektivitas pemanfaatan teknologi dalam berbagai metode pembelajaran daring yang dikaitkan dengan tujuan akhir belajar sebagai input penting bagi tenaga pengajar dalam pemilihan teknologi dan metode yang akan dikuasai.
\end{abstract}

Kata kunci: pembelajaran, daring, teknologi, efektivitas

\section{PENDAHULUAN}

Wacana penerapan pembelajaran jarak jauh secara daring banyak disuarakan dalam strategi pembelajaran di berbagai lembaga pendidikan, khususnya pada masa pandemi ketika pembelajaran dengan metode tatap muka konvesional tidak dimungkinkan. Hal ini mengakibatkan wacana yang semula disuarakan tetapi dengan berhati-hati dan secara perlahan masih dipelajari dan belum banyak diterapkan, tiba-tiba menjadi sebuah kebutuhan yang harus segera dilaksanakan tanpa memberi kesempatan untuk ditelaah secara detail. Dengan kondisi penerapan yang terdesak waktu seperti itu, tidak heran adopsi yang dilakukan oleh sejumlah pihak dari kalangan edukasi mendapat banyak kritisi dari masyarakat luas yang secara tiba-tiba pula harus menyesuaikan diri dengan metode pembelajaran daring.

Berbagai persiapan yang seyogyanya perlu dilakukan dalam perancangan suatu modul belajar daring di antaranya adalah mempelajari berbagai metode pembelajaran daring untuk disesuaikan dengan kondisi dan kebutuhan pembelajaran, mempelajari karakteristik peserta didik daring untuk dikaitkan dengan kesesuaian metode pembelajaran yang dipakai, mempelajari berbagai teknologi untuk menentukan teknologi ajar yang paling sesuai dengan sumber daya baik pendidik maupun peserta didik dan yang paling efektif dalam penyampaian materi ajar. Dengan pelaksanaan yang terkesan mendadak, setiap Langkah tersebut di atas tidak dapat dilaksanakan dalam waktu yang cukup untuk analisa. Lebih dari itu pendidik dipaksa untuk segera menentukan metode dan teknologi yang akan dipakai dengan cepat dan sedikit pertimbangan dengan bekal sedikit atau bahkan tanpa data, keahlian dan pengalaman. Akibatnya, proses perancangan model pembelajaran daring saat ini terkesan eksperimental, mayoritas di antara model tersebut mendapat kritik dari khalayak luas yang tampak dari 
berbagai komentar pada sosial media maupun berbagai artikel dan kritik yang dimuat oleh berbagai media.

Oleh karena itu, masalah sebenarnya yang dihadapi dalam perencanaan modul ajar daring adalah bagaimanakah model metode yang tepat untuk peserta ajar saat ini dan teknologi apa yang perlu dipelajari untuk penerapan model tersebut. Penelitian ini ditujukan untuk merumuskan pemakaian metode dan teknologi yang sesuai untuk pembelajaran daring dengan menelaah keterkaitan antara berbagai metode dan hasil yang dicapai oleh peserta saja. Pertimbangannya adalah target dan tujuan pembelajaran baik secara konvensional ataupun daring adalah pencapaian kompetensi dari peserta ajar yang biasanya diukur dari hasil evaluasi pembelajaran mereka, sehingga keberhasilan suatu modul ajar berbanding lurus dengan pencapaian kompetensi tersebut.

Model pembelajaran daring selama ini dianggap merupakan preferensi dari generasi pembelajar pada masa kini. Hal tersebut dikarenakan mayoritas pembelajar pada masa kini berada pada kelompok generasi Z yang dilahirkan sekitar tahun 1995 hingga 2012 (Stillman \& Stillman, 2017). Generasi $Z$ dilukiskan sebagai generasi yang amat terbiasa dengan keberadaan teknologi digital (Stillman \& Stillman, 2017) dan bahkan teknologi tersebut telah bertransformasi menjadi keseharian mereka dan bukan merupakan hal yang baru lagi (Pearson, 2018). Bahkan menurut suatu riset, banyak dari antara mereka menganggap diri mereka terlalu terkait dan menghabiskan terlalu banyak waktu dengan teknologi, khususnya gadget (Anderson \& Jiang, 2018).

Pesatnya perkembangan teknologi internet turut memberikan sumbangsih dalam fenomena tersebut karena dengan akses yang cukup cepat, maka secara instan banyak hal dapat dicari dan diperoleh secara cepat dengan berselancar di dunia maya, tidak seperti generasi sebelumnya yang masih sempat mengalami masa ketika keterbatasan teknologi menghambat proses pencarian informasi secara digital. Selain amat terbiasa dan mahir dengan berbagai macam gadget dan teknologi digital sejak usia dini, generasi ini juga cepat menemukan solusi dengan mengandalkan teknologi internet melalui ketukan jari mereka (Stillman \& Stillman, 2017). Hal ini membuat mereka juga terbiasa untuk secara mandiri mencari materi untuk dipelajari dan dengan demikian dapat menemukan solusi atas permasalahan yang dihadapi (Pearson, 2018). Dengan demikian akan lebih sulit untuk mendeteksi kehadiran masalah dengan generasi ini karena masalah tersebut disimpan dan dicari solusinya secara mandiri.

Terkait dengan preferensi belajar yang dipilih, banyak studi menggarisbawahi bahwa generasi $Z$ sangat nyaman dengan pemakaian video sebagai alat bantu belajar mereka. Dalam riset yang diadakan oleh The Harris Poll, ditemukan bahwa sekitar $82 \%$ responden adalah pemakai Youtube (Pearson, 2018), angka ini terpaut cukup jauh yaitu sekitar $15 \%$ dari generasi sebelumnya yaitu milenial yang hanya berada pada $67 \%$. Lebih dari itu sekitar $66 \%$ responden secara rutin mengunjungi video sharing website untuk. Sekitar 59\% responden juga menganggap Youtube sebagai platform belajar mereka. Seluruh hasil studi tersebut menunjukkan kecenderungan pemilihan metode belajar kombinasi visual dan auditory sebagai model belajar ideal bagi generasi $Z$.

Walau kebanyakan studi menyarankan metode yang menitikberatkan visualisasi melalui video dalam proses pembelajaran bagi generasi Z, Jurenka dan rekan menemukan dalam riset mereka bahwa mayoritas generasi ini malah menyatakan diri mereka sebagai pembelajar auditory yaitu sebesar 52.5\% (Jurenka, Stareček, Vraňaková, \& Caganova, 2018). Selain itu, riset oleh The Harris Poll juga menunjukkan walaupun generasi ini cukup mandiri dalam pencarian informasi dan pembelajaran, peran pengajar masih dianggap signifikan oleh mereka, hal ini ditunjukkan oleh $78 \%$ responden yang menyatakan pentingnya peran guru dalam pembelajaran dan pengembangan pribadi mereka (Pearson, 2018). Hal ini sebenarnya sejalan dengan karakteristik generasi ini yang walau mandiri dalam belajar dan cenderung belajar melalui media, tetapi juga merupakan generasi yang gemar berkolaborasi. Dibandingkan milenial, generasi Z lebih banyak memakai sosial media untuk tetap terhubung 
atau bahkan bertukar pesan dengan rekannya. Lebih lanjut, studi lain juga menemukan bahwa 80\% responden dari generasi $Z$ menikmati belajar dengan sistem kolaborasi bersama teman (Barnes \& Noble College, 2016), 64\% di antaranya menyebutkan diskusi kelas sebagai model ajar yang paling bermanfaat dalam belajar. Mengenai hasil pembelajaran dengan sistem kolaborasi dan diskusi, ditemukan bahwa sistem ini walaupun dengan jumlah waktu tatap muka yang lebih minim terbukti lebih efektif dalam penyampaian materi dibandingkan dengan model ceramah tradisional (Baepler, Walker, \& Driessen, 2014).

\section{METODE}

Dengan mempertimbangkan berbagai temuan dalam studi sebelumnya, penelitian ini memilih beberapa metode ajar yang dianggap sesuai dengan karakteristik peserta ajar saat ini, kemudian berusaha melakukan analisa keterkaitan antara berbagai metode yang dianjurkan dan dikaitkan dengan preferensi peserta didik sendiri serta hasil yang dicapai oleh peserta didik. Data penelitian diperoleh melalui sampling survey yang dibagikan kepada peserta ajar yang mengalami proses belajar mengajar seluruhnya dalam bentuk daring. Survai yang diberikan akan memotret ketersediaan dan keterbatasan sarana prasarana dari peserta ajar, kemudian dilanjutkan dengan memotret pencapaian prestasi terbaik dan terburuk mereka serta berbagai unsur yang mungkin memicu pencapaian tersebut. Selanjutnya survai juga akan memotret kemampuan bertahan dan penyerapan materi dari setiap metode ajar yang diusulkan serta preferensi pribadi responden terhadap berbagai metode tersebut. Survai dibagikan mayoritas kepada mahasiswa dan pelajar pendidikan tinggi dan berdomisili di Indonesia.

\section{HASIL}

Dengan berlangsungnya proses belajar daring secara menyeluruh yang dialami oleh seluruh jenjang pendidikan, maka hasil pencarian data ini dapat dengan baik memetakan fakta mengenai pembelajaran daring. Survai dirancang untuk memotret ketersediaan sarana prasarana, model dan hasil pembelajaran daring, serta preferensi dan kesulitan yang dialami peserta ajar. Responden survai adalah peserta pembelajaran daring selama minimal tiga bulan. Survai dibagi dalam beberapa pokok bahasan berikut :

1. Ketersediaan sarana dan prasarana yang meliputi:

- $\quad$ Lokasi peserta didik dan ketersediaan jaringan internet

2. Subjek belajar dengan hasil berupa nilai terbaik dan terburuk

3. Metode yang dipakai dalam subjek belajar dengan nilai terbaik dan terburuk

4. Tingkat kemampuan penyerapan dan tingkat kebertahanan pada setiap metode belajar

5. Preferensi metode ajar

6. Kesulitan yang dialami saat proses belajar daring serta kemandirian dalam mengatasinya.

Dari hasil survai tampak bahwa mayoritas responden saat ini memiliki sarana dengan teknologi yang cukup memadai untuk proses belajar daring. Hal ini terbukti dari Gambar 1 tambah bahwa hampir seluruh responden yaitu $95.9 \%$ ada di rumah sendiri dan setidaknya lebih dari 60\% memiliki fasilitas internet melalui wifi yang memadai, sebagian kecil memiliki cadangan untuk fasilitas tersebut. 

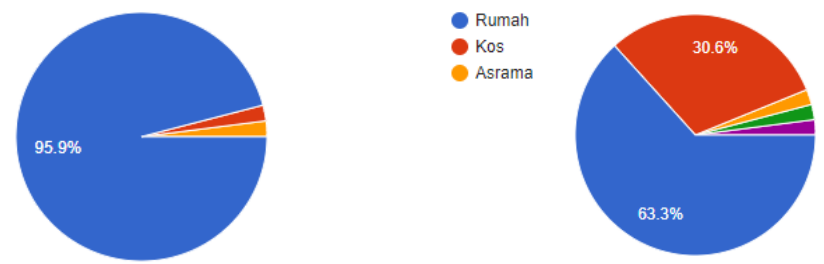

- Unlimited dengan wif

Menggunakan wifi namun kadang terpaksa beli quota karena wifi koneksi

nya kurang lancar

- kalo wifi down, pakai kuota

- Kadang wifi kadang kuota tergantung

adanya gangguan sinyal

Gambar 1. Lokasi tinggal dan ketersediaan fasilitas internet.

Selanjutnya berdasarkan hasil survai mata ajar yang mendapat banyak nilai baik didominasi oleh mata ajar yang membutuhkan praktik semacam praktikum dengan persentase total lebih dari 75\% seperti tampak pada Gambar 2.

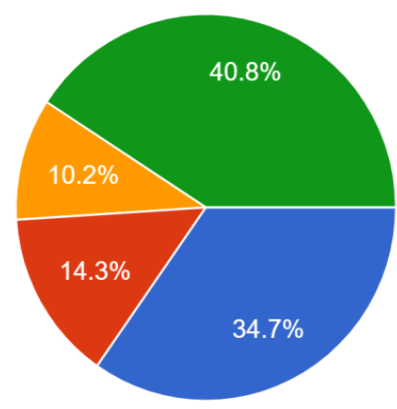

Programming

Konsep (misalnya Pancasila, Agama, Ekonomi, Geografi)

Berhitung (misalnya Matematika, Statistika)

Praktek Non Programming

Gambar 2. Mata pelajaran dengan nilai terbaik.

Sedangkan mata ajar yang mendapat nilai kurang baik mayoritas terjadi pada mata ajar praktik pemrograman dan mata ajar konsep secara tepat sama yaitu dengan persentase $36.7 \%$ seperti tampak pada Gambar 3.



Programming

Konsep (misalnya Pancasila, Agama, Ekonomi, Geografi)

Berhitung (misalnya Matematika, Statistika)

Praktek Non Programming

Gambar 3. Mata pelajaran dengan nilai terburuk.

Setiap mata ajar dapat memakai berbagai macam metode dan teknologi dalam proses belajar daringnya. Metode yang banyak dipergunakan oleh berbagai mata ajar yang banyak mendapatkan nilai baik didominasi justru oleh metode konvensional yaitu pemberian modul dan materi ajar dalam bentuk teks sebanyak 67.3\% dan disertai dengan video penjelasan materi oleh pengajar sebanyak 61.2\% seperti ditampilkan pada Gambar 4. Kemudian metode yang cukup banyak dipakai lainnya adalah yang mengakomodasi kolaborasi dalam bentuk group chat (49\%) dan online meeting (53.1\%) melalui berbagai media online screen meeting yang tersedia. Uniknya hasil yang serupa dengan sedikit perbedaan komposisi terjadi pada 
pertanyaan tentang metode ajar yang dipakai pada mata ajar dengan nilai yang kurang baik yaitu dominasi modul ajar (67.3\%) dan video (63.3\%) serta diikuti oleh online meeting $(57.1 \%)$ dan group chat (38.8\%). Mengenai faktor yang mendorong keberhasilan mendapatkan nilai yang baik serta yang mengakibatkan kegagalan dalam belajar, seluruh responden tidak terlalu mengkaitkan dengan metode dan teknologi pembelajaran yang dipakai tetapi menunjuk kepada konten, kemampuan pribadi, dan evaluasi serta penugasan sebagai faktor utama keberhasilan atau kegagalan.

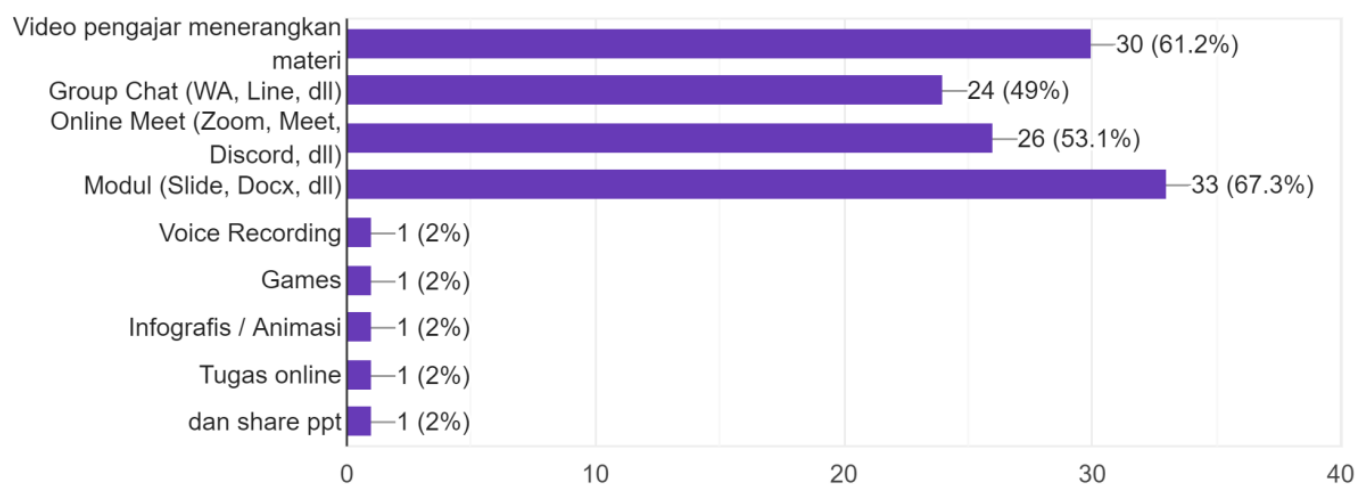

Dalam hal kemampuan berkonsentrasi dan bertahan mengikuti proses pembelajaran, rata-rata untuk setiap metode peserta ajar mampu berkonsentrasi dalam durasi antara 10 hingga 30 menit sebelum bosan. Namun, media online meeting terbukti mampu membuat peserta ajar mampu bertahan dalam durasi yang lebih lama hingga 1 jam.

Sehubungan dengan tingkat pemahaman materi, tampak dari Tabel 1 bahwa responden merasa memperoleh tingkat pemahaman yang cukup tinggi jika pembelajaran dieksekusi dalam bentuk video, infografis, online meeting dan games. Sedangkan jika pembelajaran daring dilakukan dengan memberikan modul, group chat atau voice record, responden mayoritas menganggap bahwa tingkat pemahaman mereka hanya mencapai tingkat menengah saja. Catatan khusus perlu diberikan pada video, online meet, games dan infografis/animasi yang tidak mencatat pemahaman materi terendah sama sekali.

\section{Tabel 1}

Tingkat Pemahaman Materi

\begin{tabular}{clccccc}
\hline No & \multicolumn{1}{c}{ Metode } & $\mathbf{1}$ (Terendah) & $\mathbf{2}$ & $\mathbf{3}$ & $\mathbf{4}$ & $\mathbf{5}$ (Tertinggi) \\
\hline 1 & Video Penjelasan & $0 \%$ & $4.3 \%$ & $14.9 \%$ & $59.6 \%$ & $21.3 \%$ \\
2 & Group Chat & $10.7 \%$ & $10.7 \%$ & $50 \%$ & $25 \%$ & $3.6 \%$ \\
3 & Voice Record & $14.3 \%$ & $7.1 \%$ & $57.1 \%$ & $14.3 \%$ & $7.1 \%$ \\
4 & Online Meet & $0 \%$ & $4.4 \%$ & $33.3 \%$ & $44.4 \%$ & $17.8 \%$ \\
5 & Modul & $10.3 \%$ & $20.5 \%$ & $38.5 \%$ & $30.8 \%$ & $0 \%$ \\
6 & Games & $0 \%$ & $0 \%$ & $14.3 \%$ & $57.1 \%$ & $28.6 \%$ \\
7 & Infografis / Animasi & $0 \%$ & $0 \%$ & $25 \%$ & $58.3 \%$ & $16.7 \%$ \\
\hline
\end{tabular}

Saat responden ditanya mengenai apakah mereka mengharapkan masing-masing metode diterapkan dalam proses pembelajaran daring mereka, seperti tampak dalam Tabel 2, hampir seluruh metode pembelajaran mendapatkan tanggapan positif; artinya, mayoritas responden mengharapkan semuanya itu. Hanya voice recording yang mendapatkan tanggapan negatif, yaitu hampir semua responden menyatakan tidak suka dan tidak mengharapkan 
pemakaiannya. Selain itu group chat dan games ternyata juga tidak terlalu diharapkan keberadaannya.

Catatan penting perlu diberikan juga bahwa dari seluruh metode yang diharapkan tersebut ternyata justru video penjelasan dan modul dalam bentuk teks menjadi dua metode yang paling banyak diharapkan oleh responden. Sebesar $55.1 \%$ responden menyatakan sangat mengharapkan video, dan $42.9 \%$ menyatakan sangat mengharapkan adanya modul.

Tabel 2

Tingkat Kesukaan/Mengharapkan Metode

\begin{tabular}{clccccc}
\hline No & \multicolumn{1}{c}{ Metode } & $\mathbf{1}$ (Terendah) & $\mathbf{2}$ & $\mathbf{3}$ & $\mathbf{4}$ & $\mathbf{5}$ (Tertinggi) \\
\hline 1 & Video Penjelasan & $0 \%$ & $2 \%$ & $8.2 \%$ & $34.7 \%$ & $55.1 \%$ \\
2 & Group Chat & $6.1 \%$ & $14.3 \%$ & $26.5 \%$ & $28.6 \%$ & $24.5 \%$ \\
3 & Voice Record & $28.6 \%$ & $26.5 \%$ & $24.7 \%$ & $4.1 \%$ & $6.1 \%$ \\
4 & Online Meet & $2 \%$ & $8.2 \%$ & $24.5 \%$ & $28.6 \%$ & $36.7 \%$ \\
5 & Modul & $0 \%$ & $4.1 \%$ & $20.4 \%$ & $32.7 \%$ & $42.9 \%$ \\
6 & Games & $14.3 \%$ & $8.2 \%$ & $26.5 \%$ & $24.5 \%$ & $26.5 \%$ \\
7 & Infografis / Animasi & $6.1 \%$ & $6.1 \%$ & $32.7 \%$ & $26.5 \%$ & $28.6 \%$ \\
\hline
\end{tabular}

Mengenai kesulitan dalam proses pembelajaran daring, tampak bahwa berbagai kesulitan yang dihadapi mayoritas mengenai masalah komunikasi dan perhatian yang mudah teralihkan. Hal lain yang juga banyak disebutkan adalah mengenai koneksi internet yang terkadang kurang stabil. Mayoritas responden menyatakan dapat mengatasi permasalahan dengan mencari sendiri sumber informasi lain secara daring ataupun menghubungi teman dan pengajar secara daring.

\section{BAHASAN}

Cukup mengejutkan bahwa data yang diperoleh dengan mayoritas responden sedang menempuh pendidikan tinggi menunjukkan bahwa keterkaitan antara metode pembelajaran daring dan keberhasilan pencapaian kompetensi tidak tampak kuat. Tampak bahwa baik mata ajar yang baik maupun kurang baik pencapaiannya memakai metode ajar yang kurang lebih sama. Selain itu responden sendiri juga tidak menyebutkan metode pembelajaran sebagai faktor penentu keberhasilan atau kegagalan mereka. Tampaknya generasi ini cukup mandiri untuk menyelesaikan permasalahan belajar mereka sendiri. Hasil penelitian ini sebenarnya juga cukup sejalan dengan hasil studi yang menyimpulkan bahwa tidak tampak perubahan signifikan terhadap learning performance dalam situasi pembelajaran tradisional dan sistem elearning (Thai, De Wever, \& Valcke, 2017).

Menarik juga untuk dicermati bahwa responden tidak meletakkan pengharapan mereka kepada modul yang mereka anggap memudahkan pemahaman mereka dalam belajar. Malahan mereka lebih mengharapkan model pembelajaran konvensional yang dipindahkan dalam bentuk digital seperti video ceramah dan modul pembelajaran. Sedangkan metode yang mereka akui sangat mudah dipahami cenderung tidak terlalu diharapkan seperti metode games dan infografis.

Hal lain yang juga perlu menjadi perhatian dalam penerapan metode ajar adalah pendeknya rentang perhatian mereka dalam semua metode ajar kecuali yang dekat dengan sistem kolaborasi seperti online meeting. Hal ini semakin menekankan bahwa generasi pembelajar pada saat ini suka berkolaborasi dalam belajar. 


\section{SIMPULAN}

Berdasarkan hasil penelitian tersebut, dapat disimpulkan bahwa metode pembelajaran konvensional yang disesuaikan dengan metode daring masih cukup efektif dalam mengarahkan peserta ajar mencapai kompetensi yang diharapkan. Tetapi perlu juga diingat bahwa rentang perhatian dan konsentrasi mereka cukup rendah, oleh karena itu perlu dipertimbangkan efisiensi waktu dalam penyusunan metode ajar. Selain itu untuk meningkatkan antusiasme metode belajar perlu diseimbangkan dengan menyisipkan beberapa metode yang bersifat kolaboratif seperti online meeting dan beberapa metode yang disukai seperti animasi dan games.

Saat ini penelitian ini meneropong berbagai mata ajar yang dilaksanakan secara daring dengan berbagai metode ajar yang diterapkan. Dengan lingkungan data yang cukup heterogen saat ini, ada kemungkinan hasil yang diperoleh berkurang validitasnya. Untuk selanjutnya perlu penelitian lanjut dengan meneropong suatu mata ajar tertentu dengan penerapan berbagai model pembelajaran agar didapatkan hasil yang lebih valid.

\section{PUSTAKA ACUAN}

Anderson, M \& Jiang, J 2018, 'Teens, social media \& technology'. Pew Research Center. Retrieved from http://www.pewinternet.org/2018/05/31/teens-social-mediatechnology-2018/

Baepler, P, Walker, JD \& Driessen, M 2014, 'It's not About seat time: Blending, fipping, and efficiency in active learning classrooms', Computers \& Education, Vol. 78, pp. 227-236. doi:10.1016/j.compedu.2014.06.006.

Barnes \& Noble College 2016, 'Getting to know Gen Z: Exploring middle and high schoolers' expectations for higher education' Retrieved from https://www.bncollege.com/wpcontent/uploads/2018/09/Gen-Z-Report.pdf

Jurenka, R, Stareček, A, Vraňaková, N \& Caganova, D 2018, 'The learning styles of the generation group $Z$ and their influence on learning results in the learning process', 16th International Conference on Emerging eLearning Technologies and Applications (ICETA), 251-260, doi: 10.1109/ICETA.2018.8572186.251-260. 10.1109/ICETA.2018.8572186.

Pearson 2018, 'Beyond millenials: The next generation of the learners. Viewed August 2020, https://www.pearson.com/content/dam/one-dot-com/one-dotcom/global/Files/news/news-annoucements/2018/The-Next-Generation-ofLearners_final.pdf

Stillman, D \& Stillman, J 2017, 'Gen Z @ work: How the next generation is transforming the workplace', DAS Creative LLC.

Thai, NT, De Wever, B \& Valcke, M 2017, 'The impact of a flipped classroom design on learning performance in higher education: Looking for the best "blend" of lectures and guiding questions with feedback', Computers \& Education, Vol. 107, doi: 10.1016/j.compedu.2017.01.003. 